amateurs in meteorology were arranged, five of which were vacation courses at the Field Study Centres of Malham Tarn, Preston Montfort and Dale Fort, and three week-end courses at Lasham, Longmynd and Dunstable. Grants for youth service in the new quinquennium will be substantially for refurbishing and improving existing youth clubs. A grant of $£ 12,750$ payable over 5 years from the beginning of 1960 has been promised to the Central Council for the Care of Cripples to establish and develop the Homecrafta Advisory Association for the Disabled.

\title{
THE REGIONAL RESEARCH LABORATORY, HYDERABAD
}

$\mathrm{T}$ HE annual report for 1959-60* of the Regional Research Laboratory, Hyderabad, is a substantial attractively produced volume printed on hand-made paper manufactured by the Laboratory. It includes lists of research staff, auxiliary technical staff and administrators' staff and of publications and patents, and gives fairly full details of research projects in progress. Most of the projects relate to some industrial process or product, but increasing emphasis is laid on the fundamental aspects of applied problems. A Specialists' Committee, under the chairmanship of Prof. M. S. Thacker, has been appointed to examine the research programmes and make recommendations broadly on the future scope of the research programmes undertaken by the Laboratory.

The work of the Laboratory continues to range over a wide field. In oils and fats, the keeping quality of castor oil and cottonseed oil claimed much attention, as well as the preparation of derivatives. A series of programmes on surface coatings dealt with dehydrated castor oil, its isomerization and styrenation, and the preparation of varnishes from dehydrated castor oil, as well as the preparation of alkyds, emulsion paints, the weathering of paints and the use of cashewnut shell liquid. Syntheses in the quinoline, isoquinoline and thieno-pyrimidine series were directed to the preparation of compounds of potential pharmacological interest, while a process for the manufacture of phenylacetic acid was re-examined, and 8 -hydroxyquinoline and 5 -chloro -7 -iodo-8-

* Regional Research Laboratory, Hyderabad. Annual Report, 1959-60. Pp. xiv + 217. (Hyderabad: Regional Research Laboratory 1961.) hydroxyquinoline synthesized for treatment of amcebic dysentery. Schemes relating to essential oils and aromatic chemicals deal with palmarosa oil, Indian einnamon leaf oil and the utilization of Indian turpentine. In addition to entomological work on insecticides, investigations have been carried out on the effect of X-rays on the biological and biochemical characteristics of the spermatozoa of insects.

In biochemistry, the microbiological production of calcium and ferrous gluconate and of eitric acid, the effect of cell concentration on the biological properties of individual cells in cell suspensions, and the biosynthesis and metabolism of proteins and nucleic acids have been examined. Programmes dealing with fuel cover the low-temperature carbonization of noncaking Indian coals and the utilization of products of the low-temperature carbonization of coal. Activated carbons and bleaching earths continue to receive attention, and there are programmes dealing with titanium pigments, the manufacture of white cement from felspar and the preparation of catalysts for the low-pressure hydrogenation of tar. Physico-chemical investigations dealt with the mineralogical composition of the bleaching earths, spectro-photometric work on tar acids from low-temperature carbonization, the surface properties and heat of wetting of absorbents and catalysts.

Under chemical engineering is included work on the vapour-liquid equilibrium of fatty acids and tar acids; the fluidized activation of carbon; pilot plant production of lævulinic acid and lounginin (a synthetic flavouring agent); and pilot-plant investigations in the milling of cotton seed and eastor seed.

\section{BIORHEOLOGY AND MICROCIRCULATION}

\begin{abstract}
GOLLOWING a reception at the Hadassah Visitors' Club, a seminar on biorheology and microcirculation was opened on April 24 at the Medical School, Jerusalem, by Dr. K. J. Mann, the general director of Hadassah, and delegates were also welcomed by Prof. M. Rachmilewitz, dean of the medical school, Hebrew University.

Dr. E. Davis (Jerusalem) introduced the symposium with a paper on the general nature and problems of microcirculation as studied by optical and electron microscopy. A main problem is how the capillaries change in diameter--whether passively in response to changes in blood content, or actively in response to nervous or chemical stimuli. How red cells pass through the apparently intact capillary is also still a mystery, nor are the spontaneous changes in calibre
\end{abstract}

and rate of flow of blood in the small vessels under. stood.

Introducing the biorheological aspect, Dr. G. W. Scott Blair (Reading, England) outlined briefly the history of the application of rheology, "the study of the deformation and flow of matter", to biological systems. Poiseuille, a pioneer of rheology, and Bingham, who named this branch of physics and organized the first society of rheologists, both worked on problems of blood-flow. Biorheologists now study many other systems, such as muscle, protoplasm, cervical mucus, synovial fuids, bronchial mucus, intraocular and cerebrospinal fluids, strength of bones, etc.

Dr. H. Harders (Hamburg, Germany) stressed the technical difficulties involved in direct microscopic observations of microcirculation in vivo. But the 